\title{
Definition of HCV Reactivation [Letter]
}

\author{
Abdurrahman Kaya $\mathbb{D}^{\prime}$ \\ Sibel Yıldız Kaya ${ }^{2}$ \\ 'Department of Infectious Disease, \\ Istanbul Training and Research Hospital, \\ Istanbul, Turkey; ${ }^{2}$ Department of \\ Infectious Disease, Sungurlu State \\ Hospital, Istanbul, Turkey
}

\section{Dear editor}

We have read with great interest the paper by Lensen et al. ${ }^{1}$ They reported a case of HCV reactivation developing following a COVID 19 vaccination. However, we have some concerns regarding the case.

Firstly, the patient had decompensated cirrhosis in 2015. However, its etiology was not clearly mentioned. It should have been specified in the text.

Secondly, she was diagnosed with hepatitis C virus infection in 2007. The tests including HCV-RNA and genotype were not available and it was not known whether she achieved a sustained viral response. Also, she had slightly increased liver enzymes since 2011. We think it is probably to be caused by $\mathrm{HCV}$.

Thirdly, more importantly, the term "reactivation of HCV infection" is used for patients resolved from the infection, namely a positive HCV antibody test and a negative for HCV RNA. ${ }^{3}$ However, it is not known in this case. Also, reactivation of $\mathrm{HCV}$ infection is defined as a rise in the HCV RNA level of at least $1 \log _{10} \mathrm{IU} / \mathrm{mL}$ from baseline, as HCV RNA levels in chronically infected patients may fluctuate by about $0.5 \log _{10} \mathrm{IU} / \mathrm{mL}^{2,3}$ It is crystal clear that the patient does not meet the criteria for a case definition because follow-up HCV RNA levels were not present. In the patient, it could be only stated that she had hepatitis with the elevation of liver enzymes. Due to findings including fever, elevated CRP and somnolence, and abdominal pain, the systemic infection including sepsis, cholangitis and spontaneous bacterial peritonitis are primarily considered in this case. In the light of these data, it is impossible to state that the patient had reactivation of HCV infection developing following a COVID-19 vaccination.

\section{Disclosure}

The authors report no conflicts of interest for this communication.

\section{References}

1. Lensen R, Netea G, Rosendaal FR. Hepatitis C virus reactivation following COVID-19 vaccination-A case report. Int Med Case Rep J. 2021;14:573-576. doi:10.2147/IMCRJ.S328482

2. Torres AH, Hosry J, Mahale P. Hepatitis $\mathrm{C}$ virus reactivation in patients receiving cancer treatment: a prospective observational study. Hepatology. 2018;67(1):36-47. doi:10.1002/hep.29344

Correspondence: Abdurrahman Kaya Department of Infectious Disease, Istanbul Training and Research Hospital, Istanbul, Turkey

Tel +9050661 I3328

3. Mahale P, Kontoyiannis DP, Chemaly RF, et al. Acute exacerbation and reactivation of chronic hepatitis C virus infection in cancer patients. $J$ Hepatol. 2012;57(6):1177-1185. doi:10.1016/j. jhep.2012.07.031

Email dr.abdkaya@hotmail.com 
Dove Medical Press encourages responsible, free and frank academic debate. The content of the International Medical Case Reports Journal 'letters to the editor' section does not necessarily represent the views of Dove Medical Press, its officers, agents, employees, related entities or the International Medical Case Reports Journal editors. While all reasonable steps have been taken to confirm the content of each letter, Dove Medical Press accepts no liability in respect of the content of any letter, nor is it responsible for the content and accuracy of any letter to the editor.

International Medical Case Reports Journal

\section{Publish your work in this journal}

The International Medical Case Reports Journal is an international, peer-reviewed open-access journal publishing original case reports from all medical specialties. Previously unpublished medical posters are also accepted relating to any area of clinical or preclinical science. Submissions should not normally exceed 2,000 words or 4

Submit your manuscript here: https://www.dovepress.com/international-medical-case-reports-journal-journal published pages including figures, diagrams and references. The manuscript management system is completely online and includes a very quick and fair peer-review system, which is all easy to use. Visit http://www.dovepress.com/testimonials.php to read real quotes from published authors. 